\title{
LEGITIMASI HUKUM ADAT BALI DALAM KARYA SASTRA KULTURAL
}

\author{
I Kadek Adhi Dwipayana dan Ida Bagus Gede Bawa Adnyana \\ Program Studi Pendidikan Bahasa Indonesia dan Daerah, FPBS IKIP PGRI Bali \\ Jalan Seroja, Tonja, Denpasar Utara, 085738841774 \\ surel: adhidwipa88@gmail.com
}

\author{
Informasi Artikel: \\ Dikirim:13 Juni 2019; Direvisi: 13 Juli 2019; Diterima: 16 Juli 2019 \\ DOI: $10.26858 /$ retorika.v12i2.9362
}

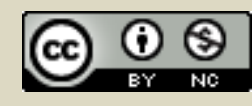

RETORIKA: Jurnal Bahasa, Sastra dan Pengajarannya berada di bawah lisensi Creative Commons Attribution-NonCommercial 4.0 International License.

ISSN: 2614-2716 (cetak), ISSN: 2301-4768 (daring) http://ojs.unm.ac.id/retorika

\begin{abstract}
Legitimacy of Balinese Customary Law in Cultural Literature Works. This article talks about the legitimacy of Balinese customary law and the reinterpretation of the authors of Balinese customary law in cultural literary works. The source of research data comes from the collection of "Bunga Jepun" short stories by Fajar Arcana, "Mandi Api" by Aryantha Soethama, Novel "Tarian Bumi" by Oka Rusmini, and "Incest" by Wayan Artika. The research data was collected by the library study method and then analyzed based on a qualitative descriptive approach which has several mechanisms, namely reduction, presentation of data, and drawing conclusions. The results of the study indicate that the legality of Balinese customary law in question in cultural literature is about the customary law of marriage, the law of inheritance, the law of neglect (exclusion), and the ritual law of malik sumpah. These customary laws become a polemic and are discussed in literary works because they are unable to provide justice for the people and tend to be discriminatory. These customary laws are polemic and are discussed in literary works because they are unable to provide justice among indigenous people.
\end{abstract}

Keywords: legitimacy, the Balinese costom law, cultural literature

Abstrak: Legitimasi Hukum Adat Bali dalam Karya Sastra Kultural. Artikel ini mengungkapkan tentang legitimasi hukum adat Bali serta reinterpretasi pengarang terhadap hukum adat Bali dalam karya sastra kultural. Sumber data penelitian berasal dari kumpulan cerpen "Bunga Jepun" karya Fajar Arcana, "Mandi Api" karya Aryantha Soethama, Novel "Tarian Bumi" karya Oka Rusmini, dan "Incest" karya Wayan Artika. Data penelitian dikumpulkan dengan metode studi kepustakaan kemudian dianalisis berdasarkan pendekatan deskriptif kualitatif yang memiliki beberapa mekanisme, yaitu reduksi, penyajian data, dan penarikan simpulan. Hasil penelitian menunjukkan bahwa legalitas hukum adat Bali yang dipersoalkan dalam karya sastra kultural adalah tentang hukum adat perkawinan, hukum pewarisan, hukum kesepekan (pengucilan), dan hukum ritual malik sumpah. Hukum-hukum adat tersebut menjadi polemik dan diperbincangankan dalam karya sastra karena tidak mampu memberikan keadilan di kalangan masyarakat adat.

Kata kunci: legitimasi, hukum adat Bali, sastra kultural 
Permasalahan lokalitas tentang adat atau tradisi seolah-olah memiliki daya tarik tersendiri bagi para pengarang etnik Bali sehingga tidak pernah tuntas untuk dibicarakan dan dikritisi dalam karya sastra (Putra, 2008). Permasalahan tentang lokalitas Bali yang kerap diperbincangkan para pengarang dalam karya sastra adalah tentang hukum dan tradisi adat Bali. Panji Tisna adalah salah satu pengarang lokal Bali yang selalu konsisten berbicara tentang permasalahan sosio-logis yang berkenaan dengan adat Bali hal itu dapat dilihat dalam karya sastranya yang berjudul Ni Rawit Cetti Penjual Orang (1933) dan Sukreni Gadis Bali (1953). Rasta Sindhu dalam cerpen fenomenalnya yang dimuat di majalah horizon, yaitu Ketika Kentongan Dipukul di Bale Banjar (1969) adalah representasi problematika sosiokultural di Bali tentang sistem stratifikasi sosial yang mengakibatkan pertikaian antarkeluarga puri. Demikian juga Putu Wijaya dalam karya sastranya yang berjudul Bila Malam Bertambah Malam (1971) dan Putri I dan II (2004) dengan sinis menyindir adat yang otoritatif dan tanpa kompromistis menggugat kemapanan tradisi Bali.

Hukum adat memiliki pemahaman tentang aturan atau tata cara berkehidupan masyarakat Hindu Bali, seperti menjalankan etika krama de$s a$, ayah-ayahan (kewajiban), pelaksanaan sistem perkawinan, pewarisan, sanksi, ritual/ upacara dan lain-lain (Windia, 2015). Hukum adat Bali ini dituangkan dalam bentuk bisama (aturan lisan) maupun dalam bentuk awig-awig (aturan tertulis), warga yang melanggar aturan dikenai sanksi sosial, moral, atau ritual/magis, yang disesuaikan sima atau loka dresta (aturan lokal) setempat. Sanksi adat pada esensinya berpedoman pada nilai-nilai keagamaan yang bertujuan untuk mengembalikan keseimbangan magis dan batin wilayah desa adat (restutitio in integerum) (Windia, 2015). Itu artinya secara esensial hukum adat Bali bersifat otoritatif yang berfungsi sebagai kontrol dan rekayasa sosial, ketetapannya adalah mutlak dan perintah bagi warga adat, sehingga harus ditaati dan dilaksanakan. Dalam praktinya hukum adat Bali masih menyisakan banyak celah sehingga menimbulkan persepsi ketidakadilan bagi sebagian kalangan. Sebut saja hukum adat Bali tentang sistem perkawinan antarkasta, sistem pewarisan, dan sanksi sosial kesepekan masih menyisakan banyak perdebatan yang belum tuntas.
Problematika hukum adat muncul disebabkan oleh perbedaan persepsi dan interpretasi dalam memahami ketetapan hukum adat dalam dinamika kultural di Bali. Unsur-unsur subjektivitas seperti sentimenisme dan egosentrisme tidak bisa dipungkiri terkadang terkontaminasi ke dalam ketentuan hukum adat sehingga melahirkan chaos bagi masyarakat adat. Sadnyini (2016) menyatakan bahwa dalam konteks hukum adat Bali, sangat sulit untuk menciptakan persepsi keadilan di tengah-tengah masyarakat, ketidakpuasan pasti selalu muncul. Terlebih lagi dominasi feodal dalam hukum adat menimbulkan ketidakpuasan persepsi publik, sehingga kepercayaan terhadap hukum adat menjadi berkurang. Fenomena inilah yang mendapatkan perhatian serius dari pengarang-pengarang etnik Bali dalam karya sastranya, seperti "Bunga Jepun" karya Putu Fajar Arcana, "Mandi Api" karya Gde Aryantha Soethama, "Tarian Bumi" karya Oka Rusmini, dan "Insect" karya I Wayan Artika.

Melalui karya sastra pengarang mencoba menyuarakan pandangan dunia suatu kelompok sosial, trans-individual subject (Goldmann dalam Yasa, 2012). Para pengarang Bali menyikapi dan membedah fenomena hukum adat dengan cara pandang dan pemikiran kritisnya melalui media karya sastra. Mereka menggambarkan secara detail egosentrisme, otoritatifisme, bahkan senti-menisme terefleksikan di dalam hukum adat Bali yang telah melahirkan konflik interpersonal. Tidak bisa dipungkiri bahwa hegemoni adat telah menciptakan dua kubu masyarakat, pro dan kontra tradisi sehingga menimbulkan pertentangan persepsi publik antara bertahan atau berpaling pada tradisi Bali (Dwipayana dan Artajaya, 2018). Secara kritis para pengarang menyinggung permasalahan geneologis seperti hukum pewarisan adat di Bali, hukum kesepekan (pengucilan), dan hukum perkawinan antarkasta.

Penelitian sejenis, baik berupa hasil penelitian maupun artikel di jurnal ilmiah pernah dilakukan oleh beberapa penulis, di antaranya Artawan (2010) dengan judul Potret dan Perjuangan Kultural Wanita Bali dalam Novel-novel Panji Tisna, Putu Wijaya, dan Oka Rusmini, Kusumawati (2011) Pertentangan Kasta dalam Kebudayaan Bali: Kajian Hegemoni dalam Tarian Bumi Karya Oka Rusmini, Dama-yanti (2014) Seksualitas Perempuan Bali dalan Hegemoni Kasta: Kajian Kritik Feminis pada Dua Novel Karangan Oka Rusmini, Sujaya (2014) Wacana Pengucilan Sosial dalam Cerpen "Ku- 
buran Wayan Tanggu”, Dwipayana (2017) Hegemoni Ideologi Feodalistis dalam Karya Sastra Berlatar Sosio-kultural Bali. Keseluruhan penelitian tersebut memiliki kesamaan, yaitu menggunakan teori sosiologi maupun feminisme sebagai pisau bedah untuk menganalisis objek penelitian masing-masing. Penelitian di atas sama-sama mengkaji sastra dari perspektif mak-ro. Namun demikian, secara kompleks pembahasan mendalam tentang legitimasi hegemoni hukum adat Bali dalam karya sastra kultural serta reinterpretasi pengarang etnik Bali terhadap hukum adat Bali dalam gagasan tekstualnya masih perlu dilakukan. Dari hasil analisis tersebut, secara implisit diperoleh gambaran yang jelas tentang upaya pengarang lokal Bali dalam mengintrospeksi, merekonstruksi, dan menyikapi hukum adat Bali dari perspektif sosiokultural dalam karya sastra.

Legitimasi hukum adat Bali dalam karya sastra kultural dikaji menggunakan beberapa teori, seperti sosiologi sastra, semiotika sastra, dan feminisme. Teori sosiologi sastra digunakan sebagai "pisau bedah" untuk mengkaji permasa-lahan sosiologis yang berkaitan dalam aspek pengarang, teks kesusastraan, dan aspek sosio-kultural yang melibatkan hukum adat Bali. Sosiologi sastra menurut Ratna (2008: 3) adalah hubungan yang mencerminkan keterikatan antara karya sastra dengan masyarakat, tradisi dan budaya. Keterikatan antara sastra dan masyarakat memiliki keterkaitan dialektik sehingga dapat ditemukan kualitas interdependensi antara sastra dan masyarakat. Goldmann (dalam Yasa, 2012) mengemukakan bahwa sastra bukan hanya perwujudan atau bentuk dari refleksi realitas yang merupakan kecenderungan kesadaran kolektif, tetapi merupakan puncak koherensi dari berbagai kecenderungan terhadap kesadaran kelompok sosial. Lebih lanjut Swingewood menyatakan bahwa karya sastra merupakan refleksi atau refraksi sosial. Refleksi sosial yang dimaksudkan adalah suatu ekses dari sebuah interaksi sosial dari masyarakat di tengah sistem yang dinamis dan cenderung mengalami perubahan yang meliputi perubahan komposisi masyarakat, sistem sosial, struktur sosiologis, dan perubahan lingkungan kemasyarakatan. Karya sastra menurut perspektif sosiologis tidak bisa dilepaskan dengan fenomena sosial. Fenomena sosial merupakan salah satu kerangka dasar yang menciptakan hubungan dialogis antara pengarang sebagai produser dan pembaca atau masyarakat seba- gai konsumen. Pemahaman terhadap feno-mena sosial dalam wujud karya sastra tidak bisa hanya dapat dilihat dalam tataran teks saja. Karya sastra sesungguhnya dibentuk oleh kondisi sosial budaya yang melatari proses penciptaan karya sastra tersebut yang dalam hal ini adalah tentang legalitas hukum adat Bali. Pemahaman terhadap karya sastra menuntut pula pemahaman terhadap interelasi maupun interaksi pengarang dan karya sastra terhadap unsur-unsur sosial, seperti sistem tradisi, struktur sosial, ideologi, mata pencarian, dan norma-norma sosial.

Selain teori sosiologi sastra, teori femenisme juga digunakan dalam kerangka menelusuri akibat atau efek yang ditimbulkan oleh ketentuan hukum adat dalam konteks perkawinan dan pewarisan yang cenderung diskriminatif terhadap perempuan dalam karya sastra. Feminisme memberikan fokus perhatian pada representasi perempuan dalam karya sastra. Feminisme menurut Fakih (2008) adalah sebuah gerakan atau perjuangan gender. Feminisme merupakan perjuangan dalam rangka mentrans-formasikan sistem yang dahulu tidak adil menuju sistem yang lebih adil bagi perempuan dan laki-laki. Hakikat feminisme adalah gerakan trans-formasi sosial. Puncak cita-cita feminisme adalah menciptakan sebuah tatanan yang lebih baik dan lebih adil untuk kaum perempuan dalam per-gaulan secara sosial. Perbedaan perspektif gender di masyarakat telah melahirkan streotipe negatif bagi perempuan. Streotipe tentang perempuan di masyarakat dianggap sebagai ketentuan kodrati atau lahiriah. Stereotif yang sebetulnya merupa-kan konstruksi sosial dan akhirnya terkukuhkan menjadi kodrat kultural yang telah melahirkan istilah marginalitas, subordinat, kekerasan atau penyiksaan (violence) bagi perempuan.

Teori semiotika sastra juga digunakan dalam penelitian ini dalam kerangka menafsirkan dan menginterpretasikan tanda, simbol ataupun lambang yang tertuang di dalam ketetapan hukum adat Bali. Teori semiotika sastra sangat penting digunakan dalam memahami dan menerjemahkan simbol-simbol, tanda, ataupun lambang yang identik dengan masyarakat Bali. Masyarakat Bali sangat kaya dengan tanda, simbol, dan lambang yang kerap digunakan dalam aspek teologis, ritual, maupun dalam menjalankan ketetapan hukum adat. Semiotika sastra juga dapat diartikan sebagai ilmu yang mempelajari berbagai objek, peristiwa, atau keseluruhan kebudayaan sebagai tanda di dalam karya sastra. Tanda 
itu diartikan sebagai sesuatu yang bersifat representatif, mewakili sesuatu yang lain berdasarkan konvensi tertentu. Konvensi yang memungkinkan suatu objek, peristiwa, atau gejala kebudayaan menjadi tanda disebut juga sebagai kode sosial.

\section{METODE}

Penelitian terhadap novel Tarian Bumi karya Oka Rusmini, Incest karya I Wayan Artika, Mandi Api karya Aryantha Soethama, dan Bungan Jepun karya Putu Fajar Arcana merupakan suatu penelitian yang beranjak dari persoalan sosiologis dalam karya sastra dengan dipayungi studi kultural (culture study). Karya sastra berlatar kultural Bali tersebut dapat dikatakan sebagai representasi dari realita yang dibalut dengan problematika sosial-budaya dalam masyarakat Bali. Beranjak dari pandangan tersebut, penelitian ini tergolong ke dalam penelitian deskriptif kualitatif yang memiliki ciri-ciri sebagai berikut: (1) kontekstual, (2) kolaboratif, (3) interprettatif, (4) interaktif, dan (5) peneliti sebagai human instrument / instrumen kunci.

Data dalam penelitian ini adalah legitimasi hukum adat Bali dan upaya dekonstruksi dan reinterpretasi terhadap hukum adat Bali dalam karya sastra kultural. Sumber data penelitian meliputi novel Tarian Bumi karya Oka Rusmini, Incest karya I Wayan Artika, antologi cerpen Mandi Api karya Aryantha Soethama, dan antologi cerpen Bungan Jepun karya Putu Fajar Arcana.

Metode pengumpulan data yang digunakan dalam penelitian ini adalah studi kepustakaan. Metode ini dilakukan dengan cara cara mengambil data dari buku-buku, kitab-kitab, literature, atau teks-teks kesusastraan. Dalam penelitian ini, data diambil dari karya sastra yang berlatar sosio-kultural Bali, seperti novel Tarian Bumi karya Oka Rusmini, Incest karya I Wayan Artika, Mandi Api karya Aryantha Soethama, dan Bungan Jepun karya Putu Fajar Arcana. Teknik yang digunakan dalam metode studi kepustakaan ini adalah teknik baca dan teknik catat. Untuk mengidentifikasi masalah karya sastra dibaca dengan cermat secara keseluruhan kemudian melakukan pencatatan data sesuai dengan masalah penelitian. Metode studi kepusatakaan ini digunakan dalam pengumpulan data pe- nelitian dengan harapan dapat memecahkan masalah dalam penelitian ini.

Langkah analisis data dilakukan dengan menggunakan metode deskriptif kualitatif. Metode ini dilakukan dengan menggunakan beberapa langkah operasional, yaitu reduksi data, penyajian data, dan penarikan simpulan.

Proses reduksi data secara simultan dilakukan melalui proses pengidentifikasian dan pengkodean. Hal itu kemudian diikuti dengan pengklasifikasian, dan penafsiran menggunakan teori sosiologi sastra, teori semiotika dan feminisme. Setelah data melewati reduksi, masalah yang dikaji dalam penelitian disajikan secara deskriptif kualitatif. Data hasil reduksi tersebut disajikan dengan menggunakan uraian naratif ataupun penggambaran dengan menggunakan kata-kata. Perlu ditekankan bahwa, data yang disajikan menggunakan uraian naratif tersebut adalah hasil identifikasi dan pengklasifikasian yang dilakukan pada tahap reduksi. Langkah terakhir dalam analisis data adalah penarikan simpulan dari hasil temuan pada proses penyajian data. Penarikan simpulan dilakukan setelah data yang diperoleh disajikan menggunakan uraian naratif.

\section{HASIL DAN PEMBAHASAN}

\section{Hasil}

Secara umum hukum adat Bali yang dikupas dalam kumpulan cerpen Bunga Jepun, Mandi Api, Tarian Bumi, dan Incest meliputi, hukum perkawinan antarkasta, hukum pewarisan adat Bali, hukum kesepekan (pengucilan), dan hukum ritual malik sumpah.

\section{Hukum Perkawinan Adat Bali dalam Karya Sastra Kultural}

Secara geneologis masyarakat di Bali masih memegang teguh warisan yang bersifat feodal dengan mengklasifikasikan diri mereka dalam sistem wangsa (Brahmana, Kesatria, Wesya, dan Sudra) sebagai wujud kesetiaan menjaga tradisi maupun ketidakberdayaan melawan hegemoni tradisi. Pengaruh sistem stratifikasi sosial melahirkan beberapa jenis perkawinan adat di Bali, seperti perkawinan menek wangsa dan perkawinan nyerod. Selain dua jenis perkawinan di atas, juga ada jenis perkawinan 
nyentana. Jenis perkawinan nyentana biasanya dilakukan bila suatu keluarga tidak memiliki keturunan laki-laki.

\section{Perkawinan Menek Wangsa (Naik Kasta)}

Adat masyarakat Bali dengan sistem kekerabatan patrilinialnya memberikan ruang bagi perempuan jaba wangsa naik derajat bila melakukan perkawinan dengan laki-laki Tri Wang$s a$. Perempuan jaba yang menek wangsa mendapatkan penghormatan di mata masyarakat yang sederajat dengan panggilan jero. Hal yang kontradiktif dihadapi Luh Sekar meskipun sudah naik derajat dan mendapatkan gelar Jero. Di lingkungan keluarga griya Jero Kenanga masih mengalami ketertindasan secara sosial dan psikologis. Sesungghnya gelar Jero dapat dimaknai sebagai identitas pemisah antara perempuan berdarah asli bangsawan dengan perempuan jaba yang mendapatkan gelar kebangsawanan dengan cara melakukan perkawinan anuloma (Dwipayana dan Artajaya, 2018). Berdasarkan feminist legal theory, perempuan dalam perkawinan anuloma bukanlah naik derajat. Bila dicermati dengan saksama ternyata naik derajat hanya di lingkungan keluarga asalnya sendiri. Artinya setelah menjadi Jero, keluarga perempuan berkewajiban memberikan bentuk-bentuk penghormatan, sedangkan di pihak keluarga suaminya tetap memperlakukan Jero sebagai perempuan jaba wangsa (Sadnyini, 2016).

Di dalam masyarakat Bali, berkembang sebuah fanatisme yang diciptakan oleh golongan bangsawan sendiri untuk melegalkan hegemoninya bahwa perempuan yang telah mengalami kenaikan derajat (menek wangi) dilarang memakan surudan (bekas sesajen) dan dilarang muspa (sembahyang) di sanggah keluarga terda-hulu karena dapat menurunkan kembali derajatnya sebagai jaba wangsa. Aturan yang paling tidak logis harus diterima Jero Kenanga ketika dilarang memandikan dan nyumbah mayat ibunya. Griya berdalih memandikan dan nyumbah mayat seorang jaba wangsa berarti telah menghapus nilai karat kebangsawanan Jero Kenanga yang telah diberikan oleh pihak keluarga griya.

"Aturan itu malah makin menjadi-jadi. Luh Sekar tidak boleh menyentuh mayat ibunya sendiri. Dia juga tidak boleh memandikan dan menyembah tubuh kaku itu. Sebagai keluarga griya, Luh Sekar duduk di tempat yang tinggi sehingga bisa menyaksikan jalannya upacara dengan lengkap. Telaga tahu hati ibu berdarah, bernanah. Dan makin hari bau busuknya makin terasa. Telaga merasakan luka itu" (Tarian Bumi: 63).

Sebagaimana wanita Bali pada umumnya, Jero Kenanga mengejawantahkan penerimaan takdir sebagai sesuatu yang kodrati dalam kehidupannya sebagai perempuan yang telah mengalami perubahan menjadi seorang istri dari laki-laki Brahmana. Mematuhi tradisi baginya adalah keharusan untuk menjaga kehormatan gelar jero yang telah disandang meskipun mengorbankan cerita kehidupan masa lalu beserta segala kecintaannya terhadap keluarga.

Hampir serupa dengan kejadian yang dialami Luh Sekar dalam Tarian Bumi, Kadek Sumerti dalam cerpen Tembok Puri karya Gde Aryantha Soethama juga mengalami permasalahan dilematis ketika memilih jalan perkawinan menek wangsa. Meskipun sudah menyandang gelar jero dan menjadi bagian dari keluarga seorang kesatria di puri, Sumerti merasa tertekan karena kebebasannya sebagai manusia dibatasi oleh aturan-aturan tradisi puri yang terkesan tendesius. Konflik batin seorang Sumerti memuncak ketika keluarganya berencana melaksanakan upacara metatah (potong gigi) untuk Sumerti dan adik-adiknya. Secara adat dan tradisi seorang anak perempuan harus melangsungkan upacara potong gigi di rumah asalnya, kendatipun Sumerti sudah menjadi warga puri. Syarat berat dan ekstrem pun diberikan keluarga puri apabila Sumerti ingin melangsungkan upacara metatah di rumah asalnya. Oleh sesepuh puri Sumerti tidak diperkenankan menggunakan balai bekas saudara-saudaranya pada saat upacara berlang-sung, ia harus metatah di atas balai-balai khusus. Persyaratan ini melukai perasaan keluarga Sumerti karena mereka merasa derajatnya direndahkan oleh pihak keluarga puri.

“Secara adat Kadek harus metatah di rumah-
nya, kendati ia sudah jadi warga puri. Orang
tuanya yang akan menanggung seluruh biaya
upacara. 'Semestinya kau me-tatah sebelum
kawin, tapi dulu Ayah tak punya cukup uang.
Mintalah restu puri karena kau harus pulang
metatah,' minta ayah Kadek" (Tembok Puri:
4).

Aryantha Soethama menggambarkan suatu hal yang kontradiktif terjadi di dalam situasi puri memasuki era saat ini. Di satu sisi, puri di- 
gambarkan sudah mulai terbuka dengan perubahan era modern yang ditandai dengan penerimaan keluarga puri atas pernikahan Ngurah Parwata dan Sumerti, namun di sisi lain pihak puri masih menunjukkan fanatisme kebangsawanannya dengan mengisyaratkan perlakukan yang berbeda harus diberikan kepada Sumerti saat pelaksanaan upacara metatah. Permasalahan geneologis perkastaan masih dipertentangkan dan menjadi penghambat hubungan keluarga Sumerti dengan puri. Hal ini menunjukkan bahwa embrio ideologi feodal masih berkembang di kalangan keluarga puri meskipun sudah memasuki era modern.

\section{Perkawinan Nyerod (Turun Kasta)}

Representasi perkawinan nyerod (turun kasta) dilakukan oleh tokoh perempuan Ida Ayu Telaga dalam novel Tarian Bumi karya Oka Rusmini. Ida Ayu Telaga dikisahkan memilih melangsungkan perkawinan dengan seorang laki-laki keturunan jaba wangsa bernama I Wayan Sasmitha. Ida Ayu Telaga dianggap telah melanggar etika tradisi keluarga griya karena tidak melakukan perkawinan pepadan antarwangsa Brahmana. Telaga, tidak lagi dipanggil dengan sebutan Ida Ayu, menurut tradisi derajatnya kini telah setara dengan keluarga suaminya. Oka Rusmini mencoba menggugat 'kebenaran' yang dijustifikasi oleh tradisi ketika aturan yang mengerdilkan kemanusiaan dan memarginalkan peranan seorang perempuan dalam konteks perkawinan adat Bali. Melalui tokoh Ida Ayu Telaga, Oka Rusmini mencoba membuka mata publik bahwa etika tradisi semacam rantai yang membelenggu hak-hak kemanusiaan seorang perempuan dalam menentukan pilihan hidup dalam konteks perkawinan.

\footnotetext{
"Telaga merasa orang-orang selalu le-bih tahu daripada dirinya sendiri. Padahal, mereka sama sekali tidak tahu seperti apa perasaan Telaga ketika kawin dan hidup sebagai perempuan Sudra untuk yang per-tama kalinya. Wayan hanya bisa mem-belikan kebaya dan kain yang kasar. Te-laga benarbenar melatih dirinya untuk menanggalkan seluruh busana kebang-sawanannya. Semua untuk cinta. Untuk perhatian, untuk kasih sayang yang tidak pernah ia dapatkan dari laki-laki" (Tarian Bumi: 149).
}

Secara sosial, stratifikasi di Bali dijaga oleh tradisi yang sangat otoritatif, bahkan diper- kuat juga legalitasnya oleh etika keluarga. Pelanggaran terhadap etika keluarga mengakibatkan si pelaku dikenai sanksi berdasarkan kesepakatan keluarga, baik berupa pelaksanaan ritual maupun dikeluarkan dari wangsa atau klan. Pelanggaran terhadap etika keluarga ini disebut dengan istilah tulah (tidak hormat) atau durwaka (durhaka) kepada leluhur sehingga wajib dikenai sanksi, baik sosial maupun psikologis (Wignjosoebroto, 2002).

Oka Rusmini merepresentasikan legalitas penurunan derajat seorang Ida Ayu Telaga diperkuat dengan pelaksanaan ritual pattiwangi di Pemerajan Griya. Pattiwangi merupakan ritual penurunan derajat seorang perempuan yang telah melakukan perkawinan nyerod dengan laki-laki dari kalangan jaba wangsa. Ritual pattiwangi dilakukan dengan cara menginjak kepala Telaga oleh mertuanya sendiri sebagai simbol penurunan derajat. Menurut Artadi (dalam Sadnyini, 2014: 186) masyarakat Bali memiliki kebiasaan yang sudah terwarisi secara geneologis perihal tuduhan yang disematkan kepada pelaku nyerod yang dianggap telah menodai keharmonisan keluarga, sehingga perlu mengembalikan kestabilan melalui sebuah ritual upacara. Kebiasaan masyarakat Bali tersebut terlahir dari sebuah konsensus yang sangat sulit untuk dihilangkan karena alasan keyakinan terhadap nilainilai religious magis.

\begin{abstract}
"Masih satu upacara yang harus dilakukan-nya agar benar-benar menjadi perempuan sudra. Patiwangi.Pati berarti mati, wangi berarti keharuman. Kali ini Telaga harus membunuh nama Ida Ayu yang telah dibe-rikan hidup padanya. Nama itu tidak boleh dipakai lagi. Tidak pantas. Hanya memba-wa kesialan lain" (Tarian Bumi: 172).
\end{abstract}

Mekanisme perkawinan nyerod (turun kasta) biasanya dilakukan dengan cara diam-diam atau disebut dengan istilah ngerorod (kawin lari) karena si pelaku perkawinan tidak mendapatkan persetujuan dari pihak keluarga tri wang$s a$. Kasus agak berbeda dialami oleh Anak Agung Sagung Mirah dengan Wayan Jirna dalam cerpen "Bohong" karya Aryantha Soethama, mereka berdua mendapatkan restu namun masih diwajibkan melakukan perkawinan ngerorod (kawin lari) oleh pihak keluarga puri karena Wayan Jirna berasal dari keturunan jaba wangsa. Sebagai laki-laki jaba wangsa I Wayan Jirna tidak berhak datang ke puri melakukan proses 
memadik (meminang) Sagung Mirah, mereka diharuskan melakukan perkawinan ngerorod (kawin lari). Menurut tradisi perkawinan jenis memadik hanya berhak dilakukan oleh mereka yang pepadan (memiliki kesetaraan derajat). Secara sosiologis, perkawinan ngerorod antara Mirah dan Wayan Jirna ini sengaja direkayasa oleh pihak keluarga puri agar aib perkawinan tersebut tidak sampai di telinga kerabat puri lainnya. Perkawinan antar-kasta dipandang sebagai suatu tindakan tulah (tidak beretika) atau durwa$k a$ (durhaka) yang dapat menurunkan derajat kebangsawanan keluarga sehingga harus dirahasiakan dan dilaksanakan secara diam-diam agar kehormatan keluarga puri tidak tercemar. Secara politis, perkawinan ngerorod merupakan representasi arogansi tokoh ayah dalam mempertahankan status quo sebagai keluarga golongan bangsawan.

"Bukan masalah pelik ketika Sagung Mirah, putri sulung Agung Bargawa kawin dengan Wayan Jirna. Warga puri disunting oleh bukan berdarah bangsawan sekarang sudah lumrah. Wayan sendiri mau diterima baik oleh keluarga puri dan pernikahan mereka direstui. Tapi keluarga Wayan dila-rang datang meminang, mereka harus ka-win lari. Pihak uri akan berpura-pura tak tahu menahu rencana pernikahan itu" (Bohong: 87).

Puncak permasalahan mekanisme perkawinan ngerorod muncul ketika pihak puri memberikan persyaratan harus melakukan ritual pattiwangi. Pihak laki-laki menolak pelaksanaan ritual pattiwangi tersebut karena merupakan simbol pelecehan terhadap derajat pihak purusa. Terdapat sedikit perbedaan perspektif antara Oka Rusmini dengan Aryantha Soethama dalam menanggapi kasus upacara pattiwangi bagi pelaku perkawinan nyerod. Jika dalam novel Tarian Bumi, Oka Rusmini berpandangan bahwa ritual pattiwangi merupakan bentuk pelecehan secara sosiopsikologis terhadap personal Ida Ayu Telaga, namun menurut Gde Aryantha Soethama ritual pattiwangi adalah simbol pelecehan bagi pihak purusa. Meskipun terdapat sedikit perbedaan perspektif tentang persoalan ritual pattiwangi namun dapat disimpulkan bahwa antara Oka Rusmini dengan Gde Aryantha Soethama bersekapat pattiwangi merupakan sebuah ritual yang memiliki simbol pelecehan, baik bagi si perempuan maupun pihak keluarga purusa.
"Tak banyak? Besar, justru besar seka-li maknanya. Ini menyangkut kehormatan keluarga, 'tangkis ayah. 'Kita yang akan melengkapi upacara pernikahan anak kita dengan sesaji pati wangi. Sampai kapan pun tidak. Kita yang menentukan macam apa sesaji perkawinan Wayan. Bukan orang lain. Bukan puri,' ujar Ayah sengit" (Bohong: 88).

Perkawinan nyerod (turun kasta) juga dilakukan oleh Ida Ayu Kartika dengan seorang jaba wangsa yang bernama Darma dalam cerpen Pergi dari Griya karya Putu Fajar Arcana. Kartika dikisahkan melangsungkan perkawinan secara diam-diam (ngerorod) dengan Darma karena tidak mendapatkan persetujuan dari keluarga Kartika. Tokoh Ayah memiliki keteguhan prinsip dan fanatisme yang kuat terhadap identitas perkastaan. Atas tindakan Kartika melakukan kawin lari dengan Darma, Kartika dibuang dari komunitas griya dan tidak lagi dianggap memiliki garis keturunan Wangsa Brahmana oleh sang ayah. Tindakan laki-laki jaba wangsa yang berani menikahi perempuan tri wangsa mendapatkan bentuk pelecehan dan stigma negatif di mata masyarakat golongan tri wangsa dengan penyebutan istilah "Alangkahin karang hulu" dan "Asu mundung." Alangkahin karang hulu secara etimologi memiliki makna melangkahi kepala raja sedangkan Asu Mundung secara harfiah dapat dimaknai sebagai "anjing pencuri". Perilaku laki-laki jaba wangsa yang mengawini perempuan Tri Wangsa diasumsikan sebagai seekor "anjing" yang tidak memiliki etika. Stigma negatif ini bertahan selama bertahun-tahun hingga muncul keputusan penghapusan Paswara oleh DPRD Bali yang dianggap cacat hukum dan tendesius.

"Kartika sendiri sudah paham akan resiko.
Seluruh keluarga, bahkan kedua orang tuanya,
pasti tidak akan mengakuinya lagi sebagai
anak. Memutuskan untuk kawin dengan
seorang yang berkasta lebih ren-dah, seperti
Made Darma Sutta, menurut anggapan
ayahnya berarti keluar dari urutan-urutan
keluarga kaum Brahmana" (Pergi dari Griya:
128).

Secara yuridis formal aturan Paswara Bali telah dicabut atau dihapuskan melalui Keputusan DPRD Bali Nomor 11 Tahun 1951, namun aturan ini masih membekas secara sosiologis sehingga pola pikir feodal masih bertahan di benak sebagian masyarakat Bali (Sadnyini, 2016). 
Praktik-praktik hukum lara-ngan perkawinan nyerod yang tertuang di dalam paswara masih berjalan. Masih banyak golongan tri wangsa yang tidak ikhlas dan tidak menerima perkawinan nyerod sehingga dalam dinamikanya menimbulkan permasalahan ketika pelaku perkawinan nyerod berpisah (karena cerai atau meninggal) dengan pasangannya masing-masing. Kedudukan perempuan yang lemah dalam kon-teks perkawinan nyerod dialami langsung oleh tokoh Kartika ketika suaminya meninggal dunia saat usia perkawinan mereka masih seumur jagung. Kartika membayangkan kehidupannya ngumbang (terombang-ambing) selepas kematian suaminya, terlebih lagi sang ayah tidak pernah menyetujui perkawinan antarwangsa yang sudah ia lakukan dengan Wayan Jirna.

\begin{abstract}
"Jangan pergi, Dar...! Tiba-tiba Kartika berlari kea rah laut. Ia tak mempedulikan kain dan kebayanya basah dipukul ombak. Kerlapkerlip layar perahu seperti lambaian-lambaian yang memanggil. Kartika itulah untuk pertama kalinya Kartika merasa tidak punya pegangan lagi untuk hidup. Terombang-ambing dalam ketegangan antara tetap melawan orang tua sendiri atau bertahan di rumah mertua tanpa suami telah membuatnya jadi sebongkah kepala" (Pergi dari Puri: 130).
\end{abstract}

Di tengah masyarakat yang masih berpikiran konservatif menyoal perkawinan antarwangsa, Putu Fajar Arcana merepresentasikan tokoh mertua lelaki Kartika sebagai figur yang berpikiran rasional dan demokratis. Niatan tokoh mertua lelaki yang mengangkat Kartika sebagai anak mencerminkan pengamalan nilai-nilai keadilan, persamaan, dan kesederajatan. Tindakan tokoh mertua lelaki dengan mengangkat Kartika sebagai anak dapat dimaknai sebuah upaya penyelamatan kepada Kartika agar tidak mendapatkan status ngumbang (terombang-ambing) yang ditakuti oleh setiap perempuan tri wangsa pelaku perkawinan nyerod. Tokoh ayah dapat dipersonifikasikan sebagai oase di gurun pasir yang tandus dan menjadi penyelamat bagi keputusasaan yang dialami Kartika selepas suaminya meninggal dunia. Penggambaran oleh penulis menunjukkan kerasionalan dan kedemokratisan.

\section{Perkawinan Nyentana}

Adat masyarakat di Bali menganut sistem patrilineal yang mengenal istilah purusa dan pradana. Laki-laki dikenal dengan istilah purusa bertugas menjalankan kewajiban-kewajiban yang diwariskan leluhur, sedangkan perempuan dikatakan selaku pradana. Namun, posisi sebaliknya dijumpai dalam jenis perkawinan nyentana atau nyeburin. Dalam konteks perkawinan nyentana, pihak laki-laki dipinang oleh pihak perempuan. Perempuan bertindak sebagai pihak purusa dan laki-laki berstatus sebagai pradana. Kasus perkawinan ini lazimnya dilakukan oleh pihak keluarga yang tidak memiliki sentana atau garis keturunan laki-laki sebagai penurus sesana (kewajiban) keluarga perempuan. Dalam novel Tarian Bumi, perkawinan nyentana ini dilakukan tokoh Ida Bagus Tugur, ia dapat dipandang sebagai korban karena melepas hak dan kewajibannya di komunitas asal sebagai Purusa untuk masuk di komunitas perempuan dan menjadi pihak Pradana. Ida Bagus Tugur menyandang predikat maskulinitas dan feminitas yang dualistik terhadap sistem perkawinan nyentana ini. Sebagai laki-laki yang nyentana, di satu sisi Ida Bagus Tugur harus menjalankan kewajibannya sebagai penerus tanggung jawab keluarga pihak perempuan atau berperan sebagai Purusa, namun di sisi lain ia juga mengambil alih peranan sebagai Pradana dan harus tunduk terhadap keputusan istrinya.

"Terwujudnya impian itu telah membuat Ida Bagus Tugur merasa baru memiliki kekuasaan yang sesungguhnya. Laki-laki itu lupa, dia punya seorang anak laki-laki. Dia juga lupa telah beristri. Dia lupa bahwa pernah nyentanain" (Tarian Bumi: 15).

Predikat Ida Bagus Tugur yang dualistik dalam sistem perkawinan nyentana menyebabkan kebebasannya sebagai laki-laki diatur oleh tradisi pihak perempuan. Setiap keputusan yang diambil harus mendapatkan persetujuan dari pihak perempuan sehingga ia merasa mendapatkan kekangan baik secara sosial maupun kultural. Di Bali pelaku nyentana mendapatkan pelabelan negatif dan rendahan yang disebut dengan istilah paid bangkung. Secara etimologi istilah paid bangkung memiliki pengertian "ditarik babi betina." Istilah negatif paid bangkung ini adalah bentuk ejekan dan pelecehan yang dibuat oleh orang Bali sendiri bagi para laki-laki Bali yang berada di bawah kendali perempuan.

Perkawinan jenis nyentana juga dilakukan oleh Wardani di dalam cerpen yang berjudul "Pernikahan Wardani" karya Putu Fajar Arcana. 
Wardani mendapatkan paksaan dari orang tuanya untuk menikahi laki-laki bernama Ketut Berartha dengan melangsungkan jenis perkawinan nyentana. Dalil yang membuat orang tua Wardani memaksanya menikah dengan Berartha adalah untuk mendapatkan sentana (ahli waris) yang kelak dapat meneruskan swadharma (kewajiban) keluarga secara adat. Dalam kasus perkawinan ini, Wardani menjadi pihak purusa dan melakukan proses peminangan kepada Ketut Berartha yang berperan sebagai pihak pradana. Sebagai seorang perempuan Wardani dikisahkan tidak kuasa melawan kehendak ayahnya untuk mencari sentana meskipun dengan konsekuensi merelakan hubungan cintanya kadas dengan laki-laki yang bernama Kurnia.

\begin{abstract}
"Sebagai perempuan Bali yang tak lagi pu-nya saudara, apalah kekuatanku untuk me-lawan kehendak orang tua. Aku tak cukup berani memberontak. Karena itu...., War-dani tersedak. Ia menunduk terdiam. Aku sudah bisa menduga ke mana arah pem-bicaraannya" (Pernikahan Wardani: 145).
\end{abstract}

Perspektif agak berbeda dapat ditangkap dalam novel Tarian Bumi karya Oka Rusmini dengan cerpen Pernikahan Wardani karya Fajar Arcana. Menurut Oka Rusmini perkawinan nyentana telah membelenggu power seorang Ida Bagus Tugur karena secara adat memerankan sesana (tanggung jawab) yang bersifat dualistik di rumah pihak pradana. Namun, menurut Putu Fajar Arcana pihak yang paling dirugikan dalam sistem perkawinan nyentana adalah si perempuan itu sendiri. Wardani diceritakan berada pada posisi subordinat dalam sistem patrilineal yang memberikan peluang bagi laki-laki untuk bertindak sebagai agresor sehingga banyak menguntungkan Ketut Beratha termasuk menghabiskan warisan leluhur milik keluarga Wardani.

\section{Hukum Pewarisan Adat Bali dalam Karya Sastra Kultural}

Dalam konteks pewarisan, anak laki-laki sebagai pihak purusa mendapatkan keistimewaan penuh dengan perolehan bagian warisan peninggalan keluarga yang dominan dibanding-kan dengan anak perempuan. Seorang anak perempuan yang telah meninggalkan rumah keluarga karena melangsungkan perkawinan (ninggal kedaton) tidak berhak atas warisan peninggalan keluarga. Kenyataan seperti itu harus diterima de- ngan legawa oleh Luh Sadri sebagai seorang perempuan yang tumbuh dan hidup di lingkungan tradisi. Penaklukan perempuan ke dalam ideologi tradisi patriarki sangat tampak pada aturan pembagian hak waris yang tidak memihak Luh Sadri sebagai anak perempuan. Meski Luh Sadri sudah berpeluh-peluh berkerja keras dan menjalankan kewajiban sebagai anak perempuan membantu keberlangsungan kehidup-an keluarga tetap saja di mata tradisi Luh Sadri tidak memiliki kekuatan hak atas warisan karena hak-hak itu sepenuhnya jatuh di tangan kakaknya, I Wayan Sasmitha. Kedekatan psikologis antara Luh Gumbreg dan Luh Sadri (antara ibu dan anak) tidak memiliki daya apa pun untuk mengubah realitas bahwa Luh Sadri tetap tidak memiliki hak atas warisan keluarga. Anak perempuan seakan tidak mendapatkan pembelaan kultural dari sang ibu di tengah dominasi hegemoni sistem patriarki. Oka Rusmini melalui Tarian Bumi mempresentasikan bahwa tradisi memang benarbenar tidak dapat diajak kompromi dan melalui hegemoninya telah mengebiri hak-hak keperempuanan Luh Sadri dalam konteks urusan pewarisan.

\footnotetext{
"Menurut Adat Bali, perempuan memang tidak memiliki hak waris. Kalau Sadri ti-dak kawin, dia memang punya hak lebih tinggi dari Telaga, iparnya. Tetapi seka-rang Sadri sudah kawin. Otomatis hak itu menjadi miliki Telaga" (Tarian Bumi, 158-160).
}

Secara hak waris Luh Sadri memang kalah dibandingkan dengan I Wayan Sasmitha sebagai pihak purusa. Luh Gumbreg menyadari betul status Luh Sadri yang lemah di mata tradisi, namun naluri keibuan Luh Gumbreg terketuk dengan mencoba untuk bersikap tidak kaku dan lebih kompromistis kepada keadaan anak perempuannya. Luh Gumbreg ingin mengakhiri polemik pembagian hak waris yang melibatkan dirinya dengan anak perempuannya. Luh Gumbreg dengan berbesar hati akan memberikan Luh Sadri jiwa dana (bekal harta benda) berupa sebidang tanah asalkan Luh Sadri mau mengajak suaminya memohon di hadapan Luh Gumbreg.

\section{Hukum Kesepekan (Pengucilan) dalam Karya Sastra Kultural}

Representasi hukum kesepekan (pengucilan) nampak begitu jelas terdapat dalam cerpen berjudul Kuburan Wayan Tanggu karya Gde 
Aryantha Soethama. Melalui tokoh Wayan Tanggu Gde Aryantha Soethama mendeskripsikan kekejaman dan ketidakadilan dari penerapan hukum kesepekan (pengucilan) yang didapatkan oleh seseorang warga desa adat. Hukum kesepekan secara harfiah memiliki pengertian hukuman/sanksi adat yang diterima oleh seseorang atau sekelompok warga adat yang melanggar awig-awig (norma) adat yang disepa-kati dengan cara pengucilan. Hukuman kesepekan (pengucilan) dapat diklasifikasikan menjadi beberapa jenis, yaitu pelarangan tinggal di wila-yah desa adat, dilarang berkomunikasi, berinteraksi, atau bersosialisasi dengan warga adat lainnya, dan yang terekstrem tidak diperkenankan menggunakan fasilitas kuburan bila kelak yang bersangkutan meninggal. Di dalam cerita, hukum kesepekan ini tidak berlaku surut, artinya ketetapan hukum ini masih berlaku meskipun Wayan Tanggu sudah meninggal sehingga jenazahnya tidak diperkenankan dikuburkan ataupun dibakar di pemakaman wilayah desa adat.

"Jadi.....jazad suami hamba tetap tak bo-leh
dikubur?"

"Saya tak berhak menjawab pertanyaanmu. Kepada tokoh-tokoh adat semestinya eng-kau memohon ampun dan kebijaksana-an, karena merekalah yang membuat semua aturan ini" (Kubur Wayan Tanggu: 80).

Implementasi hukum kesepekan (pengucilan) sejatinya sangat rentan terkontaminasi politik kepentingan yang cenderung tendensius untuk menguntungkan golongan tertentu. Selain itu, sentimenisme dan egoisme pribadi juga kerap menjadi pemicu lahirnya keputusan hukum kesepekan (pengucilan). Seperti dalam cerpen Kubur Wayan Tanggu, penjatuhan hukuman kesepekan kepada Wayan Tanggu disebabkan oleh permasalahan sengketa lahan yang melibatkan warga desa dengan Wayan Tanggu. Wayan Tanggu sebagai pemilih sah lahan tegalan dinyatakan menang sengketa melawan desa adat oleh pengadilan. Di sinilah letak permasalahan sesungguhnya ketika desa adat merasa dipermalukan dan ditelanjangi oleh warganya sendiri sehingga semakin kuatlah Kepala Desa menebar kebencian dan dengki kepada Wayan Tanggu. Kemudian jadilah Wayan Tanggu berserta keluarga sebagai sosok terhakimi dan berstatus terdakwa di mata masyarakat adat karena alasanalasan yang sesungguhnya sarat kepentingan praktis.

\begin{abstract}
"Kepiluan mulai merayapi hati Luh Sasih. Ia benar-benar merasakan betapa mence-kiknya sepi terasing. Kesepian itu kian mencekamnya ketika pengadilan memutus-kan Wayan Tanggu berhak atas tegalan itu" (Kubur Wayan Tanggu: 83).
\end{abstract}

Hukum kesepekan (pengucilan) kepada sesama warga adat sesungguhnya sangat ekstrem, hukuman tersebut berbanding terbalik dengan penegakan nilai-nilai kemanusiaan di masyarakat. Gde Aryantha Soethama menyetujui bahwa hukum kesepekan adalah sebuah hokuman yang ekstrem bahkan di dalam cerita dengan tegas ia menyatakan bahwa seekor kera pun tidak membiarkan mayat sekawanannya tergeletak begitu saja. Pernyataan tersebut dapat dimaknai sebagai sebuat satire yang menyinggung kekejaman manusia terhadap sesamanya di saat kera memiliki nurani dan rasa empati yang sangat tinggi terhadap kawanannya.
"Sasih justru merasakan nasib suaminya benar-benar seperti jazad seekor kera. Ia beberapa kali mendengar cerita orang-orang sekampung, kalau kera yang mati di hutan wisata Sangeh tak dibiarkan terge-letak begitu saja, tapi dikubur oleh teman-temannya sesama kera" (Kubur Wayan Tanggu: 85).

Tidak jauh berbeda dengan permasalahan hukum kesepekan yang dibahas dalam Kuburan Wayan Tanggu, cerpen karya Fajar Arcana yang berjudul Rumah Makam juga menggambarkan bahwa hukum kesepekan sebagai hukum yang rentan ditunggangi kepentingan praktis dan sentimenisme pribadi. Agak sedikit kompleks permasalahan yang diuraikan Putu Fajar Arcana tentang akar lahirnya ketetapan hukum kesepekan (pengucilan) yang dijatuhkan kepada I Raneh. Jika dalam cerpen Kuburan Wayan Tanggu akar permasalahan yang menyebabkan lahirnya hukum kesepekan bagi Wayan Tanggu adalah tentang sengketa lahan tegalan dengan warga adat, namun di dalam cerpen Rumah Makam tokoh I Raneh dijatuhi hukuman kesepekan karena beberapa hal mulai dari perbedaan pandangan politik, perdebatan/konflik personal dengan kelihan adat, hingga sentimenisme personal karena keseluruhan anak I Raneh termasuk Susila merantau ke luar Banjar dan dianggap tidak menjalankan kewajiban selaku warga adat.

"Bagaimana ini bisa terjadi? Adat dibikin
begitu kaku, bahkan digunakan untuk meng- 
hantam orang-orang yang tidak disukai. Ini hanya dendam pribadi. Apa yang pantas dicemburui dari keluargaku?" (Rumah Makam: 4).

Penyelesaian konflik yang dipilih oleh Gde Aryantha Soethama dan Putu Fajar Arcana di dalam cerpen mereka masing-masing menimbulkan permasalahan baru. Hal itu direpresentasikan melalui tokoh Sasih maupun Susila yang sama-sama memilih untuk menguburkan jazad Wayan Tanggu dan I Raneh di dalam area pekarangan rumah mereka masing-masing. Tindakan yang diambil oleh tokoh Sasih dan Susila dapat dimaknai sebagai sebuah bentuk resistensi yang lahir dari keputusasaan karena tidak kunjung menemukan kata rekonsiliasi dengan warga desa adat.

Representasi hukum kesepekan juga terdapat dalam novel Incest karya I Wayan Artika. Novel ini bercerita tentang sanksi kesepekaan (pengucilan) yang harus diterima oleh sepasang suami istri bernama I Nyoman Sika dan Ketut Artini selama empat puluh dua hari di perbatasan desa karena melahirkan sepasang bayi kembar buncing. Menurut tradisi yang diyakini sebagian masyarakat Jelungkapi kelahiran bayi kembar buncing dikatakan aib apabila lahir di keluarga jaba Secara sosio-historis, fenomena kasus adat yang menimpa keluarga I Nyoman Sika berakar dari kepercayaan lama tentang manak salah yang diwariskan secara geneologis pada masyarakat Bali. Bayi kembar buncing dianggap sebagai manak salah bila terlahir dari golongan masyarakat jaba wangsa dikatakan akan mendatangkan bencana bagi desa. Konsep dan ketentuan sanksi adat bagi golongan keluarga jaba yang melahirkan bayi kembar buncing (manak salah) diatur dalam lontar Dewa Tatwa yang dirancang dan dibuat oleh raja sendiri pada masanya.

Sanksi adat kesepekan yang diberikan warga Jelungkap kepada keluarga I Nyoman Sika dan Ketut Artini atas kelahiran sepasang bayi kembar buncing telah melemahkan wibawa adat itu sendiri. Rasionalisme yang menjadi dasar-dasar normatif penegakan hukum tidak dijadikan sebagai parameter pemberian sanksi adat terhadap keluarga I Nyoman Sika. Selain itu, pertimbangan dari persepektif nilai-nilai humanis juga dikesampingkan warga Jelungkap sebagai bentuk kewajiban dan kepatuhan terhadap adat. Sanksi kesepekan kepada keluarga Nyoman Sika yang hanya didasari atas kepercayaan terhadap mitos masa lalu yang terkesan klise dan tidak dapat dikaji kebenaran logisnya adalah bentuk kegagalan adat memberikan perlindungan kepada warganya terhadap tindakan-tindakan diskriminatif.

\begin{abstract}
"Warga Desa Adat Jelungkap, untuk kelahiran buncing di keluarga Nyoman Sika, adat kembali mesti dijalankan. Sehabis makan pagi, silahkan pergi ke Langking Langkau, bekerja untuk membuatkan gubuk. Selama emapt puluh dua hari, kita akan mengasingkan sepasang bayi buncing itu.' Dingin dan ketus. Namun kharismatik" (Incest: 51).
\end{abstract}

\section{Hukum Upacara Malik Sumpah dalam Karya Sastra Kultural}

Dalam Incest karya Wayan Artika, dikisahkan tokoh keluarga I Nyoman Sika dan Ketut Artini tidak hanya mendapat hukum adat kesepekan (pengucilan) mereka juga mendapat-kan hukuman melaksanakan upacara malik sumpah. Upacara malik sumpah bagi masyarakat Bali memiliki pengertian sebagai upacara yang bertujuan menyucikan bhuana agung (alam semesta/ desa) dan bhuana alit (diri sendiri/ masyarakat) agar terhindar dari bencana baik niskala maupun sekala. Sanksi malik sumpah memiliki beban materiil dan psikologis yang amat berat. Nyoman Sika dikisahkan tetap bungkam dan tidak memberikan sedikit pun pembelaan diri atas hukuman yang dijatuhkan kepadanya. Kebisuan keluarga Nyoman Sika terhadap sanksi yang dijatuhkan kepada mereka adalah bentuk ketidakberdayaan seseorang terhadap hegemoni adat.

\footnotetext{
"Mendengar awal penjelasan Jero Mangku Utama, orang-orang yang hadir semuanya berdebar-debar membayangkan berapa ekor babi, ayam, dan itik yang harus mereka keluarkan untuk upacara malik sumpah. Hal ini adalah ketentuan adat juga dan bagian lain hukum untuk keluarga Jelungkap yang melahirkan anak kembar buncing" (Incest: 74).
}

Artika menyoroti upacara malik sumpah yang dijatuhkan oleh tokoh lima pemangku (pendeta) adat kepada keluarga Nyoman Sika atas kelahiran bayi kembar buncing adalah bentuk kesalahan dari penegakan hukum adat di Jelungkap. Tokoh lima pemangku (pendeta) direpresentasikan sebagi simbol ideologi masa lalu yang otoriter dalam menegakkan kuna dresta 
(tradisi lama) di desa Jelungkap tanpa celah kompromis. Melalui tokoh lima pemangku desa, Artika mencoba memberikan pandangannya tentang kecenderungan konstruksi berpikir golongan tua dalam mengambil keputusan ketika dihadapkan pada suatu kasus adat. Konsep pasang badan pemangku dalam mempertahankan kuna dresta tanpa memperhatikan konteks 'kekinian' dalam pemberian sanksi adat kepada bayi kembar buncing adalah representasi penghambatan akses reformasi tradisi yang bersifat diskriminatif.

\begin{abstract}
"Kelima orang pemangku desa itu adalah orang-orang yang menghamba kepada masa lalu dan adalah tentara-tentara adat Jelungkap, walaupun sebenarnya mereka selalu tampil dengan lengan-lengan otot yang keriput (karena usia tua). Sebaliknya, kepatuhan terhadap masa lalu yang terus dibangun dan dihidupkan menyebabkan para pemangku itu dihormati dan dipatuhi cara atau jalan bagi orang-orang Jelungkap untuk menjadi bagian masa silam dan bangga kepada Jelungkap. Dengan cara ini ada lembaga yang diam, bagaimana Jelungkap sesungguhnya tidak mau dibawa ke masa kini" (Incest: 75).
\end{abstract}

Melalui kebisuan lembaga adat di Jelungkap justru telah mendukung terciptanya kekakuan adat oleh golongan tua padahal lembaga adat mempunyai fungsi sebagai pelindung dan pengayom masyarakat. Secara konseptual, konstruksi berpikir dalam melakukan interpretasi terhadap hukum adat harus dibangun berdasarkan atas wiweka (pengetahuan atau penalaran logis) bukan atas dasar sentimenisme, egosentrisme, ataupun fanatisme sehingga dalam implementasinya dapat memberikan persepsi keadilan di masyarakat adat.

\section{Pembahasan}

Hasil penelitian terhadap karya sastra $T a$ rian Bumi, Incest, Mandi Api, dan Bunga Jepun menunjukkan bahwa antara Oka Rusmini, I Wayan Artika, Aryantha Soethama, dan Putu Fajar Arcana memiliki pemahaman yang linier bahwa hukum adat yang berlaku masih belum mampu memberikan keadilan bagi semua pihak sehingga menimbulkan polemik berkepanjangan yang belum tuntas. Penglegitimasian hukum adat dalam karya sastra sesungguhnya sebuah upaya pengarang untuk memberikan pemahaman dan melakukan redefinisi terhadap adat dan tradisi yang masih konservatif dan deskriminatif. Melalui pemahaman terhadap karya sastra Tarian Bumi, Incest, Mandi Api, dan Bunga Jepun semestinya hukum dapat menjadi mediator yang memberikan kepastian keadilan bagi masyarakat adat. Namun realitas menunjukkan bahwa hukum adat terutama yang mengatur tentang ketentuan sistem perkawinan, pewarisan, sanksi kesepekan (pengucilan), dan hukum ritual malik sumpah (bagi keluarga yang memiliki bayi kembar buncing) masih menjadi polemik berkepanjangan dari dulu hingga saat ini. Polemik ini belum mendapatkan pemecahan karena kuatnya hegemoni feodalistis yang tertanam di dalam benak masyarakat. Ideologi feodalistis ini dapat digolongkan menjadi dua bentuk yaitu yang bersifat personal dan melembaga (Dwipayana dan Artajaya (2018). Ideologi feodal yang bersifat personal terefleksikan melalui fanatisme berlebihan terhadap soroh, kulit, wangsa atau kasta. Masih melekatnya dikotomi tentang kelas atas dan bawah, penguasa dan dikuasai menyebabkan membudanya paham feodal dalam benak masing-masing individu. Ideologi feodal yang bersifat melembaga terefleksikan melalui warisan sistem adat yang otoritatif, egosentris, dan tendesius, seperti sistem perkawinan antarkasta dan sistem pewarisan yang memihak anak lakilaki.

Masalah hukum perkawinan antarkasta yang direpresentasikan oleh tokoh Telaga dalam novel Tarian Bumi telah membuka lebar mata kita bahwa adat atau tradisi telah mendeskriminasi kebebasan seorang perempuan Bali dalam menentukan pilihan hidup dalam konteks perkawinan. Permasalahan hegemoni perkastaan menjadi penghambat perempuan seperti Ida Ayu Telaga untuk memperoleh kebahagian yang hakiki dengan laki-laki yang dicintainya. Perempuan Tri wangsa seperti Telaga menda-patkan tekanan psikologis yang cukup besar, baik dalam lingkungan keluarga maupun lingkungan sosial bahwa seorang perempuan bangsawan harus menjaga kehormatan kebangsawanannya dengan melakukan perkawinan sederajat. Telaga adalah representasi perempuan Bali senyatanya yang terbelenggu oleh doktrin-doktrin ortodoks yang menggiring perempuan ke dalam kubangan penderitaan dalam konteks perkawinan. Tokoh Telaga digambarkan sebagai perempuan Bali yang visioner dan kuat meskipun berada dalam lingkaran tradisi yang memarginalkan peranannya 
sebagai seorang perempuan dalam dimensi patriarkis. Melalui tokoh Telaga seorang Oka Rusmini ingin menunjukkan cara penyikapannya terhadap adat yang tendesius dan deskriminatif terhadap perempuan. Tokoh Telaga seakan menyadarkan kita bahwa perlunya perjuangan dalam membebaskan diri dari kungkungan fanatisme tradisi yang berlebihan. Terdapat hal yang menarik dalam struktur naratif Tarian Bumi karya Oka Rusmini, tokoh Telaga diceritakan melakukan perjuangan dengan segala daya upaya untuk melawan hegemoni tradisi Griya namun tetap kandas. Telaga harus kehilangan suaminya yaitu I Wayan Sasmitha karena meninggal dunia hingga harus melakukan ritual pattiwangi (ritual penurunan derajat) yang mengguncang batinnya sebagai seorang perempuan. Hal ini menunjukkan sikap dualistik dari seorang Oka Rusmini, di satu sisi melalui tokoh Telaga ia ingin melawan tradisi yang diskriminatif secara reaksioner tetapi di sisi lain ia bersifat kompromis terhadap hegemoni adat atau tradisi.

Permasalahan perkawinan antarkasta juga ditunjukkan dalam kumpulan cerpen Mandi Api karya Aryantha Soethama. Dalam cerpen yang berjudul Bohong sepasang kekasih yang berbeda kasta yaitu Sagung Mirah dan Wayan Jirna harus melakukan mekanisme perkawinan ngerorod (kawin lari) karena secara tradisi seorang jaba wangsa (orang biasa) dilarang memadik (meminang) seorang perempuan Tri Wangsa (perempuan golongan bangsawan). Windia (2015) menyatakan bahwa di dalam hukum adat perkawinan di Bali tertuangan aturan bahwa proses memadik lazim atau cenderung dilakukan oleh pasangan laki-laki dan perempuan yang sederajat. Pada zajam kerajaan dan kolonial laki-laki jaba wangsa yang berani meminang perempuan tri wangsa mendapatkan streotipe negatif dengan penyebutan istilah "Alangkahin $\mathrm{Ka}$ rang Hulu" dan "Asu Mundung" yang tertuang di dalam aturan Peswara (Sadnyini, 2016). Alangkahin karang hulu secara etimologi memiliki makna melangkahi kepala raja sedangkan Asu Mundung secara harfiah dapat dimaknai sebagai "anjing pencuri". Perilaku laki-laki jaba wangsa yang mengawini perempuan Tri Wangsa diasumsikan sebagai orang yang berani melangkahi kepala raja dan bahkan juga disebut sebagai seekor "anjing" yang tidak memiliki etika. Stigma negatif ini bertahan selama puluhan tahun di Bali hingga muncul keputusan peng-hapusan Paswara oleh DPRD Bali yang dianggap cacat hukum dan tendesius untuk kepentingan golongan tertentu.

Kedudukan seorang perempuan di mata adat dalam konteks perkawinan antarkasta sangat lemah. Status perempuan tri wangsa yang direpresentasikan tokoh Kartika dalam cerpen yang berjudul Pergi dari Puri karya Putu Fajar Arcana menjadi ngumbang (tidak jelas atau terombang-ambing) ketika suami Kartika yang berasal dari keturunan jaba wangsa meninggal dunia. Kartika tidak bisa lagi kembali ke rumah asalnya karena ia sudah mengalami penurunan derajat melalui prosesi ritual pattiwangi. Seorang perempuan tri wangsa yang sudah mengalami penurunan derajat secara sosial kekerabatan sangat sulit diterima kembali oleh keluarga asalnya yang kini telah memiliki derajat lebih tinggi. Terlebih lagi mekanisme perkawinan Kartika dilakukan dengan perkawinan ngerorod (kawin lari) karena tidak mendapat restu dari ayahnya di puri. Tokoh Kartika merepresentasikan perempuan Bali yang tidak mendapatkan perlindungan secara konstitusional di mata adat.

Di dalam karya sastra yang berjudul $K u$ buran Wayan Tanggu karya Aryantha Soethama dan Rumah Makam karya Fajar Arcana menunjukkan bahwa hukum sesungguhnya sangat rentang ditunggangi oleh kepentingan politik praktis. Hukum kesepekan (pengucilan) yang dijatuhkan kepada masing-masing tokoh Wayan Tanggu dalam cerpen Kuburan Wayan Tanggu dan I Raneh dalam cerpen Rumah Makam ditunggangi oleh kepentingan praktis dan senti-menisme individual dari pejabat desa. Intrik-intrik yang terjadi di dalam kehidupan sosial yang melibatkan Wayan Tanggu dan I Raneh dengan masyarakat adat menyebabkannya tersisihkan di komunitas sosialnya. Aryantha Soethama dan Fajar Arcana merefleksikan salah satu sisi murah penegakan norma atau hukum adat di Bali. Melalui tokoh I Wayan Tanggu dan I Raneh, masingmasing pengarang bersepakat penjatuhan hukuman kesepakan melanggar hak-hak kemanusiaan dan konstitusi sebagai makhluk sosial karena melanggar asas persamaan dan kesamaan. Hukum kesepekan juga sejatinya melanggar ajaran agama Hindu yaitu ajaran Tat twam asi atau ajaran Manusa Pada. Hukum kesepekan yang dijatuhkan kepada Wayan Tanggu dan I Raneh tidak berlaku surut. Artinya terdakwa harus menjalankan hukuman hingga meninggal konsekuensinya adalah jasad Wayan Tanggu dan I Raneh dilarang dimakamkan dikuburan di 
wilayah desa adat setempat. Hukuman kesepekan (pengucilan) sesungguhnya dapat diklasifikasikan menjadi beberapa jenis, yaitu pelarangan tinggal di wilayah desa adat, dilarang berkomunikasi, berinteraksi atau bersosialisasi dengan warga adat lainnya dan yang terekstrem tidak diperkenankan menggunakan fasilitas kuburan bila kelak yang bersangkutan meninggal. Di dalam cerita, I Wayan Tanggu dan I Raneh mendapatkan hukuman paling ekstrem yaitu $d i$ sepekan (dikucilkan) hingga mereka mening-gal. Inilah yang kemudian menjadi kasus problematik tanpa pemecahan ketika jazad seorang terdakwa pengucilan dilarang dikubur di wilayah desa setempat. Melalui representasi tokoh Sasih dalam cerpen Kuburan Wayan Tanggu dan Susila dalam cerpen Rumah Makam, Gde Aryantha Soethama dan Fajar Arcana memiliki cara penyelesaian konflik yang hampir sama, yaitu dengan memilih menguburkan jazad Wayan Tanggu dan I Raneh di pekarangan rumah. Cara penyelesaian konflik di dalam cerita menurut (Sujaya, 2014) sesungguhnya menimbulkan permasalahan baru. Penguburan jazad di pekarangan rumah jika ditinjau dari perspektif religious magis orang Bali adalah meletehkan (mencemarkan) kesucian wilayah pekarangan dan desa adat setempat. Menurut keyakinan orang Bali untuk menyucikan kembali wilayah yang tercemar harus melalui proses upacara pembersihan alam sekala (dunia nyata) dan niskala (dunia kasat mata). Tindakan yang diambil oleh tokoh Sasih dan Susila dengan menguburkan jazad di pekarangan rumah dapat dimaknai sebagai sebuah bentuk resistensi yang lahir dari keputusasaan karena tidak kunjung mendapatkan rekonsiliasi dengan warga desa adat.

Bentuk ketidakadilan sanksi adat juga disoroti oleh Artika dalam novelnya yang berjudul Incest. Melalui tokoh I Nyoman Sika, Artika melakukan resistensi terhadap penegakan sanksi ritual malik sumpah (upacara pember-sihan) hanya karena ia memiliki bayi kembar buncing. Dalam konteks sarana, upacara malik sumpah menggunakan beberapa sarana binatang kurban, seperti kerbau, kambing, babi, ayam, dan itik dipersembahkan untuk penyucian alam sekala dan niskala. Dalam tataran pelaksanaan, sarana binatang dalam upacara malik sumpah dise-suaikan dengan tingkatan upacara (kecil, sedang, dan utama). Bagi kepercayaan warga Jelungkap kelahiran kembar buncing adalah kesalahan kolektif, sehingga pelaksanaan upacara mecaru malik sumpah harus ditanggung bersama. Meskipun demikian, tetap saja sanksi malik sumpah memiliki beban materiil dan psikologis yang amat berat karena selain harus menyiapkan semua sarana upacara, biaya upacara pastilah dominan ditanggung pihak keluarga si kembar buncing. Secara sosio-historis, fenomena kasus adat yang menimpa keluarga I Nyoman Sika berakar dari kepercayaan lama tentang manak salah (anak salah) yang diwariskan secara geneologis pada masyarakat Bali. Predikat manak salah diberikan kepada keluarga jaba/ sudra yang telah melahirkan bayi kembar buncing. Sedangkan, apabila bayi kembar buncing lahir di keluarga kerajaan akan dianggap sebagai pembawa berkah dan kemakmuran bagi wilayah desa. Konsep manak salah ini sesungguhnya diciptakan sebagai upaya penglegitimasian hegemoni kaum bangsawan atau raja untuk kepentingan pragmatisme. Kekukuhan dan keegoisan berpijak pada adat membuat pendukungnya tidak menggunakan penalaran logis dalam pelaksanaannya. Perilaku serta tindakan seakan mendapat pembenaran sehingga dalam realitasnya terkadang terjadi hambatan atau ekses yang justru menempatkan pendukung adat itu sendiri menjadi korban seperi kasus yang dialami oleh Nyoman Sika dan Ketut Artini dalam novel Incest.

\section{SIMPULAN}

Di dalam karya sastra Tarian Bumi karya Oka Rusmini, Incest karya I Wayan Artika, Mandi Api karya Aryantha Soethama, dan Bungan Jepun karya Putu Fajar Arcana masingmasing memperbincangkan legalitas hukum adat yang masih menjadi polemik karena belum sanggung memberikan keadilan di kalangan masyarakat Bali. Berdasarkan kajian terhadap keempat karya sastra tersebut didapatkan persa-maan persepsi bahwa perempuan menjadi pihak paling dirugikan dalam ketetapan sistem hukum adat, seperti sistem perkawinan antarwangsa dan sistem pewarisan. Pengaruh sistem stratifikasi sosial juga menyebabkan lahirnya beberapa jenis perkawinan adat di Bali, seperti perkawinan menek wangsa/naik wangsa (anuloma), perkawinan nyerod (pratiloma). Terdapat juga jenis perkawinan nyentana yang terlahir dari sistem garis keturunan patrilineal yang dianut masya-rakat di Bali. Dalam konteks pewarisan, anak laki-laki sebagai pihak purusa yang memiliki kewajiban 
penerus keberlangsungan keluarga mendapatkan keistimewaan penuh dengan perolehan bagian warisan peninggalan keluarga yang dominan dibandingkan dengan anak perempuan. Seorang anak perempuan yang telah meninggalkan rumah keluarga karena melangsungkan perkawinan (ninggal kedaton) tidak berhak atas warisan peninggalan keluarga. Hukum kesepekan (pengucilan) sejatinya sangat rentan terkontaminasi politik kepentingan yang cenderung tendensius untuk menguntungkan golongan tertentu. Sentimenisme juga kerap menjadi pemicu lahirnya keputusan hukum kesepekan (pengucilan). Seperti dalam cerpen Kubur Wayan Tanggu, penjatuhan hukuman kesepekan kepada Wayan Tanggu di-

\section{DAFTAR RUJUKAN}

Arcana, P. F. 2003. Bunga Jepun. Jakarta: Kompas.

Artawan, I. G. 2010. Potret dan Perjuangan Kultural Wanita Bali dalam Novel-Novel Panji Tisna, Putu Wijaya, dan Oka Rusmini. Disertasi. Denpasar: Udayana.

Artika, I. W. 2008. Incest. Yogyakarta: Penerbit Pinus.

Damono, S. D. 1984. Sosiologi Sastra Sebuah Pengantar Ringkas. Jakarta: Pusat Pembinaan dan Pengembangan Bahasa Departemen Pendidikan dan Kebudayaan.

Darmayanti, I. A. M. 2014. Seksualitas Perempuan Bali dalam Hegemoni Kasta: Kajian Kritik Sastra Feminis pada Dua Novel Karya Oka Rusmini. Jurnal Ilmu Sosial dan Humaniora 3, (2):484-494.

Dwipayana, I. K. A. 2017. Resistensi Perempuan Terhadap Hegemoni Patriarki dalam Kultur Masyarakat Bali pada Novel-novel Oka Rusmini. Stilistetika, 10:37-52.

Dwipayana, I. K. A. 2018. Potret Tirani dalam Praktik Sosiokultural di Bali dalam Cerpen Ketika Kentongan Dipukul di Bale Banjar Karya Nyoman Rasta Sindhu. Widyadari: Jurnal Pendidikan, 19 (2):1-11.

Dwipayana, I. K. A. dan Gde S. A. 2018. Hegemoni Hukum Adat Bali dalam Karya Sastra Berlatar Sosiokultural Bali. Jurnal Kajian Bali, 08 (2) 85-105.

Fakih, M. 2008. Analisis Gender dan Transformasi Sosial. Yogyakarta: INSISTPress.

Oka, R. 2007. Tarian Bumi. Jakarta: Gramedia Pustaka Utama.

Putra, I. D. 2008. Bali dalam Kuasa Politik. Denpasar: Arti Foundation. sebabkan oleh permasalahan sengketa lahan yang melibatkan warga desa dengan Wayan Tanggu.

\section{UCAPAN TERIMA KASIH}

Penelitian ini didanai melalui Hibah Penelitian Dosen Pemula tahun anggaran 2019. Penulis menyampaikan ucapan terima kasih kepada Kementerian Riset, Teknologi, dan Pendidikan Tinggi Republik Indonesia. Ucapan terima kasih disampaikan pula kepada mitra bestari yang telah memberikan saran, kritik, dan komentar untuk perbaikan artikel ini.

Ratna, N. K. 2005. Sastra dan Culture Studies: Representasi Fiksi dan Fakta. Yogyakarta: Pustaka Pelajar.

Sadnyini, I. A. 2016. Sanksi Perkawinan Terlarang di Bali Dulu dan Kini. Denpasar: Udayana University Press.

Shindu, N. R. 1969. Ketika Kentongan Dipukul di Bale Banjar. Horison, 1 (4) 27-29.

Soethama, G. A. 2006. Mandi Api. Jakarta: Kompas

Suarta, I. M. dan I Kadek A. D. 2014. Teori Sastra. Jakarta: PT Raja Grafindo Persada.

Sujaya, I. M. 2014. Wacana Pengucilan Sosial dalam Cerpen "Kuburan Wayan Tanggu" Karya Gde Aryantha Soethama. Stilistetika, 5: 98-112.

Swingewood, A. \& Diana L. 1972. The Sociology of Literature. London: Paladin.

Trisna, A. A. P. 1953. Sukreni Gadis Bali. Jakarta: Balai Pustaka.

Trisna. A. A. P. 1933. Ni Rawit Ceti Penjual Orang. Jakarta: Balai Pustaka.

Wellek, R. \& Austin W. 1977. Theory of Literature. Terjemahan Melani Budianta. 2014. Teori Kesusastraan. Jakarta: Pustaka Utama.

Wijaya, P. 2004. Putri I dan Putri II. Jakarta: PT Pustaka Utama Graffiti.

Wijaya, P. 1971. Bila Malam Bertambah Malam. Jakarta : Pustaka jaya.

Windia, W. 2015. Hukum Adat Bali: Aneka Kasus dan Penyelesaiannya. Gianyar: Dinas Kabupaten Gianyar bekerjasama dengan Udayana University Press, "Bali Shanti" Pusat Pelayanan dan Budaya Bali, dan Puslit Hukum Adat.

Yasa, I. N. 2012. Teori Sastra dan Penerapannya. Bandung: Karya Putra Darwati. 